\title{
A geographically widespread plasmid from Thiobacillus ferrooxidans has genes for ferredoxin-, FNR-, prismane- and NADH- oxidoreductase-like proteins which are also located on the chromosome
}

\author{
Clifford N. Dominy, Shelly M. Deane and Douglas E. Rawlings \\ Author for correspondence: Douglas E. Rawlings. Tel: +2721650 3261. Fax: +27 216897573. \\ e-mail: doug@molbiol.uct.ac.za
}

Department of

Microbiology, University of

Cape Town, Private Bag

Rondebosch, Cape Town

7700, South Africa
During a search for genes encoding electron transport proteins from a Thiobacillus ferrooxidans ATCC 33020 gene bank, a 19.8 kb plasmid, pTF5, which conferred increased sensitivity to the antimicrobial agent metronidazole upon an Escherichia coli mutant, was isolated and cloned in E. coli. The plasmid had an identical restriction enzyme map to a plasmid which has been found in T. ferrooxidans strains isolated from many different parts of the world. The plasmid was present at between two and four copies per genome and contained a region of approximately $5.6 \mathrm{~kb}$ which was also found on the chromosome. This region was sequenced and found to have four complete ORFs, which when translated had high percentage amino acid similarity to [3Fe-4S,4Fe-4S] ferredoxins, proteins of the FNR regulator family, prismanelike proteins and the NADH oxidoreductase subunit of a methane monooxygenase. In vitro protein analysis using an E. coli-derived transcriptiontranslation system indicated that three of the four products (FdxA, PsmA and RedA) were expressed in the heterologous system. Ferredoxins, prismane-like proteins and NADH oxidoreductases are redox-active proteins and it is likely that the proteins on pTF5 represent an electron transport system of as yet unknown function. Surprisingly, although genes for redox-active proteins have been isolated from other bacteria by screening gene banks for increased sensitivity to metronidazole, the region of pTF5 containing the genes for these proteins was not responsible for the increase in metronidazole sensitivity conferred by the plasmid. The region of pTF5 which did confer increased metronidazole sensitivity to an $E$. coli metronidazole-resistant mutant was a 319 bp region of DNA close to the origin of plasmid replication. This region contained no ORFs and was identical to that previously reported for the replicon of a $9.8 \mathrm{~kb}$ T. ferrooxidans plasmid, pTFI91.

Keywords: Thiobacillus ferrooxidans, prismane, FNR protein, ferredoxin, NADH oxidoreductase

\section{INTRODUCTION}

Thiobacillus ferrooxidans, Thiobacillus thiooxidans and Leptospirillum ferrooxidans are Gram-negative, acidophilic, mesophilic, chemoautolithotrophic bacteria

The GenBank accession number for the nucleotide sequence reported in this paper is U 73041 . which are frequently isolated from bioleaching processes used for the commercial extraction of metals such as copper, uranium and gold from sulphide-containing ores (Lundgren \& Silver, 1980; Brierley, 1982; Rawlings \& Silver, 1995). These bacteria grow as a consortium (often together with acidophilic heterotrophs, such as those of the genus Acidiphilium) in an inorganic, metalrich, low-pH (typically $1.5-2.0$ ) environment. T. ferrooxidans is the most extensively studied of the bio- 
leaching bacteria from both a physiological and genetic point of view. A number of plasmids have been isolated from strains of $T$. ferrooxidans, several of which have been studied in detail (Rawlings \& Kusano, 1994). Plasmids frequently contain non-essential genes which may increase the ability of their hosts to grow in a particular environment (Eberhard, 1989). Since T. ferrooxidans grows in an unusual environment, we have been particularly interested in investigating $T$. ferrooxidans plasmids in an attempt to identify the accessory genes they might possess.

Plasmid pTF-FC2 is the only $T$. ferrooxidans plasmid for which a functional accessory gene has been found (Clennel et al., 1995). Plasmid pTF-FC2 is a $12.2 \mathrm{kbp}$ broad-host-range, mobilizable plasmid with a replicon which is similar to the IncQ plasmid RSF1010 and a mobilization region with clear homology to the TraI region of the IncP plasmids RK2 and R751 (Dorrington \& Rawlings, 1990; Rohrer \& Rawlings, 1992). A transposon with $38 \mathrm{bp}$ inverted repeat sequences which are identical to those of Tn21 is located on pTF-FC2. This transposon, $\operatorname{Tn} 5467$, contains three accessory genes which encode a glutaredoxin, a MerR-like regulator protein and a $43 \mathrm{kDa}$ protein with similarity to multidrug resistance transport proteins. Although it has not been proven what properties the plasmid confers on $T$. ferrooxidans, when cloned in Escherichia coli the gene for the glutaredoxin has been shown to complement $E$. coli thioredoxin mutants for several thioredoxin-dependent functions (Clennel et al., 1995).

Several authors have noted that some plasmids found in T. ferrooxidans have a very wide geographic distribution (Sanchez et al., 1986; Valenti et al., 1989, 1990; Chakravarty et al., 1995). Members of one widely distributed $T$. ferrooxidans plasmid family share a highly conserved replicon, part of which is present on a $2.2 \mathrm{kbp} \mathrm{SacI}$ fragment (Chakravarty et al., 1995). One particular $T$. ferrooxidans plasmid has been isolated by workers in three different laboratories and although the estimates of its size vary slightly $(19.6-20.0 \mathrm{kbp})$, the plasmids appear to have an identical restriction enzyme map to pTF35 (Rawlings et al., 1983). This plasmid has been found in $T$. ferrooxidans strains which have originated from a bitumous coal mining effluent in Pennsylvania (Leathen et al., 1956; Chakravarty et al., 1995), a chalcopyrite mine in New Mexico (Valenti et al., 1990), a variety of sulphur spring and river water samples in the vicinity of Rome (Valenti et al., 1990; Polidoro et al., 1993) and a uranium deposit in Japan (this paper). Because of its wide geographical distribution it is possible that this $20 \mathrm{kbp}$ plasmid contains genes which are beneficial to the survival of its host.

In parallel to ongoing plasmid studies we attempted to isolate genes encoding electron transport proteins from T. ferrooxidans ATCC 33020 using a procedure which involved screening for genes which are able to activate the antimicrobial drug metronidazole. Metronidazole is active only once it has been reduced and has previously been used successfully for this purpose (Wall et al.,
1984; Santangelo et al., 1991). Our studies on plasmid biology and the search for genes for redox-active proteins converged when, using the metronidazole sensitivity screening procedure, we unexpectedly isolated a $19 \cdot 8 \mathrm{kbp}$ plasmid which conferred metronidazole sensitivity to an $E$. coli mutant. Furthermore, the plasmid had an identical restriction enzyme map to the previously reported and widely distributed plasmids, pTF35 and pTF0. We here present an analysis of a $6.0 \mathrm{kbp}$ region of plasmid pTF5 which contained genes encoding products with homology to redox-active proteins and show that this region is also present on the chromosome. An additional unexpected finding was that this region was not associated with an increase in the sensitivity of E. coli F19 to metronidazole.

\section{METHODS}

Bacterial strains, plasmids and growth conditions. Bacterial strains and plasmids are shown in Table 1. T. ferrooxidans and $L$. ferrooxidans strains were grown in $9 \mathrm{~K}$ liquid medium at $30^{\circ} \mathrm{C}$ (Silverman \& Lundgren, 1959). T. thiooxidans was grown in medium containing $50 \mathrm{mM} \mathrm{K}_{2} \mathrm{~S}_{4} \mathrm{O}_{6}, \mathrm{pH} 2.5$ (Powles et al., 1995). E. coli strains were grown in Luria broth at $30^{\circ} \mathrm{C}$ and where appropriate ampicillin $\left(100 \mu \mathrm{g} \mathrm{ml}^{-1}\right)$ was added. The T. ferrooxidans ATCC 33020 cosmid library was prepared using cosmid vector pHC79 and contained inserts of between 30 and $44 \mathrm{kbp}$ (Ramesar, 1988).

Anaerobic assays. Clones to be tested for MICs of metronidazole were transformed into $E$. coli F19 (Santangelo et al., 1991) and grown on Luria agar supplemented with $0.5 \%$ (w/v) $\mathrm{NaNO}_{3}$ and $0.5 \%(\mathrm{w} / \mathrm{v})$ glucose. A $10 \mathrm{mg} \mathrm{ml}^{-1}$ stock of metronidazole (Sigma) was diluted to test for growth of transformants at $0,5,10,15,20$ and $35 \mu \mathrm{g} \mathrm{ml}$ final concentration. Clones positive for the ability to complement an $E$. coli fnr mutant phenotype were identified and plasmid DNA extracted. This DNA was transformed into $E$. coli RM102 and incubated anaerobically $\left(\mathrm{CO}_{2} / \mathrm{N}_{2} / \mathrm{H}_{2}, 85: 10: 5\right.$, by vol.) for $4 \mathrm{~d}$ at $37^{\circ} \mathrm{C}$ on minimal media containing glycerol $(0.5 \%, \mathrm{v} / \mathrm{v}), \mathrm{NaNO}_{3}(0.5 \%)$ and ampicillin $\left(100 \mu \mathrm{g} \mathrm{ml} \mathrm{m}^{-1}\right)$ (Birkmann et al., 1987), and then examined for growth.

PFGE. This was conducted using a Beckman Geneline Transverse Alternating Field system. Total genomic DNA samples were prepared by resuspending cell cultures in SET buffer

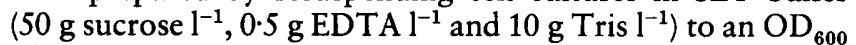
of 1 . Cells were lysed with $50 \mu \mathrm{g}$ Proteinase $\mathrm{K} \mathrm{ml}^{-1}$ (Merck) for $30 \mathrm{~min}$ at $37^{\circ} \mathrm{C}$. Samples were embedded in a lowtemperature-gelling agarose (Hispanagar) at $1 \cdot 1 \%(\mathrm{w} / \mathrm{v})$ final concentration. Samples were sliced into $20 \times 6 \times 2 \mathrm{~mm}$ plugs and Tris/EDTA containing $1 \%(\mathrm{w} / \mathrm{v})$ SDS and $50 \mu \mathrm{g}$ Proteinase $\mathrm{K} \mathrm{ml}^{-1}$ added. Samples were incubated for $48 \mathrm{~h}$ at $45^{\circ} \mathrm{C}$ and washed $(3 \times 15 \mathrm{~min})$ in ES solution $(10 \mathrm{~g}$ sodium lauryl sarcosine $\mathrm{l}^{-1}, 168 \mathrm{~g} \mathrm{EDTA}^{-1}, \mathrm{pH} 8$ ) and transferred to Tris/EDTA. Plugs were incubated in $2 \mathrm{mM}$ Pefabloc proteinase inhibitor (Boehringer Mannheim) for $16 \mathrm{~h}$ at $4{ }^{\circ} \mathrm{C}$ and then washed in Tris/EDTA. Samples for digestion with $\mathrm{XbaI}$ were preincubated in $1 \times$ restriction buffer $\mathrm{H}$ (Boehringer Mannheim) containing $1 \mu \mathrm{g} \mathrm{BSA} \mathrm{ml} \mathrm{m}^{-1}$ for $1 \mathrm{~h}$, followed by digestion in $1 \times \mathrm{H}$ buffer containing 30 units $\mathrm{XbaI}$ for $4 \mathrm{~h}$. Digested samples were washed in Tris/EDTA and the plugs stored at $4^{\circ} \mathrm{C}$ until used. Slices were equilibrated in $1 \times$ PFGE running buffer $\left(250 \mu \mathrm{l}\right.$ glacial acetic acid $1^{-1}, 0 \cdot 16 \mathrm{~g} \mathrm{EDTA}^{-1}$ and $1.2 \mathrm{~g} \mathrm{Tris}^{-1}$ ) prior to use. Agarose gels, $1 \%(\mathrm{w} / \mathrm{v})$, were made with $1 \times$ PFGE running buffer. Gels were electro- 
Table 1. Bacterial strains and plasmids

\begin{tabular}{|c|c|c|}
\hline Strain or plasmid & Relevant characteristics & Source or reference \\
\hline \multicolumn{3}{|l|}{ Strains } \\
\hline \multicolumn{3}{|l|}{ L. ferrooxidans } \\
\hline DSM 2705 & Type strain, Armenia & DSM, Darmstadt, Germany \\
\hline \multicolumn{3}{|l|}{ T. thiooxidans } \\
\hline ATCC 19377 & Type strain, Libya & ATCC, Rockville, MD, USA \\
\hline \multicolumn{3}{|l|}{ T. ferrooxidans } \\
\hline ATCC 33020 & $\mathrm{U}^{\mathrm{r}}$ isolate, Japan & ATCC, Rockville, MD, USA \\
\hline ATCC 23270 & Type strain, USA & ATCC, Rockville, MD, USA \\
\hline FC1 & $A s^{5}$ strain, South Africa & Gencor \\
\hline FC6 & As ${ }^{r}$ strain, South Africa & Gencor \\
\hline Bateman Reno & South Africa & Gencor \\
\hline Black Mountain $\mathrm{Pb}$ & South Africa & Gencor \\
\hline \multicolumn{3}{|l|}{ E. coli } \\
\hline F19 & CC118 (TnPhoA::yebB TnPhoA::pgk) & Santangelo et al. (1991) \\
\hline RM102 & MC4100 $\Delta f n r \Delta(s r l-r e c A) 306:: \operatorname{Tn} 10$ & Birkmann et al. (1987) \\
\hline \multicolumn{3}{|l|}{ Plasmids } \\
\hline pTF5 & T. ferrooxidans ATCC 33020 & This study \\
\hline pTF35 & T. ferrooxidans TF35 & Rawlings et al. (1983) \\
\hline pCD1 & pTF5 cloned into pBS-KS & This study \\
\hline pDER301 & pTF35 cloned into pBR322 & Rawlings \& Woods (1985) \\
\hline pCD100 & $\begin{array}{l}12 \cdot 9 \mathrm{~kb} \text { XbaI-HindIII pTF5 subclone in } \\
\text { pBS-KS }\end{array}$ & This study \\
\hline pCD119 & $2 \cdot 3 \mathrm{~kb}$ EcoRV subclone in pBS-KS & This study \\
\hline pCD120 & $\begin{array}{l}1.3 \mathrm{~kb} \text { amplified DNA cloned into } \\
\text { pKK } 223-3\end{array}$ & This study \\
\hline pCD150 & $5 \cdot 2 \mathrm{~kb}$ ClaI subclone in pBS-KS & This study \\
\hline pCD163 & $\begin{array}{l}1.0 \mathrm{~kb} \text { amplified DNA cloned into } \\
\text { pKK223-3 }\end{array}$ & This study \\
\hline pCD164 & $\begin{array}{l}2 \cdot 8 \mathrm{~kb} \text { amplified DNA cloned into } \\
\text { pKK223-3 }\end{array}$ & This study \\
\hline pCD200 & $\begin{array}{l}6.9 \mathrm{~kb} \text { Xbal-HindIII pTF5 subclone in } \\
\text { pBS-KS }\end{array}$ & This study \\
\hline pCD300 & $2 \cdot 2 \mathrm{~kb}$ SacI pTF5 subclone in pBS-KS & This study \\
\hline pCD313 & $\begin{array}{l}0.319 \mathrm{~kb} \text { XbaI-Sall pTF5 subclone in } \\
\text { pBS-KS }\end{array}$ & This study \\
\hline pCD400 & $2.5 \mathrm{~kb} S p h \mathrm{I}$ pTF5 subclone in pUC-BM21 & This study \\
\hline $\mathrm{pCD} 421$ & $\begin{array}{l}1.05 \mathrm{~kb} \text { HindIII-SphI subclone in pUC- } \\
\text { BM } 21\end{array}$ & This study \\
\hline pCD500 & $11.8 \mathrm{~kb}$ Sacl $\Delta$ of pCD100 in pBS-KS & This study \\
\hline pMET7 & $\begin{array}{l}\text { T. ferrooxidans cosmid library clone in } \\
\text { pHC79 }\end{array}$ & This study \\
\hline pMET17 & $\begin{array}{l}\text { T. ferrooxidans cosmid library clone in } \\
\text { pHC79 }\end{array}$ & This study \\
\hline pBS-KS & Cloning vector & Stratagene \\
\hline pUC-BM21 & Cloning vector & Boehringer Mannheim \\
\hline pHC79 & Cosmid cloning vector & Boehringer Mannheim \\
\hline pKK223-3 & $\begin{array}{l}\text { Expression vector containing tac } \\
\text { promoter }\end{array}$ & Pharmacia \\
\hline
\end{tabular}

phoresed in $1 \times$ PFGE running buffer at $150 \mathrm{~mA}$ for $14 \mathrm{~h}$ with an $8 \mathrm{~s}$ pulse time.

Determination of plasmid copy number. Dot blot analysis of T. ferrooxidans ATCC 33020 total genomic DNA and cloned
pTF5 DNA (pCD200) was used to determine the number of plasmids per genome in $T$. ferrooxidans. The amounts of genomic and plasmid DNA to be hybridized were standardized according to the relative sizes of the $T$. ferrooxidans chromosome and plasmid pTF5 assuming a copy number of 


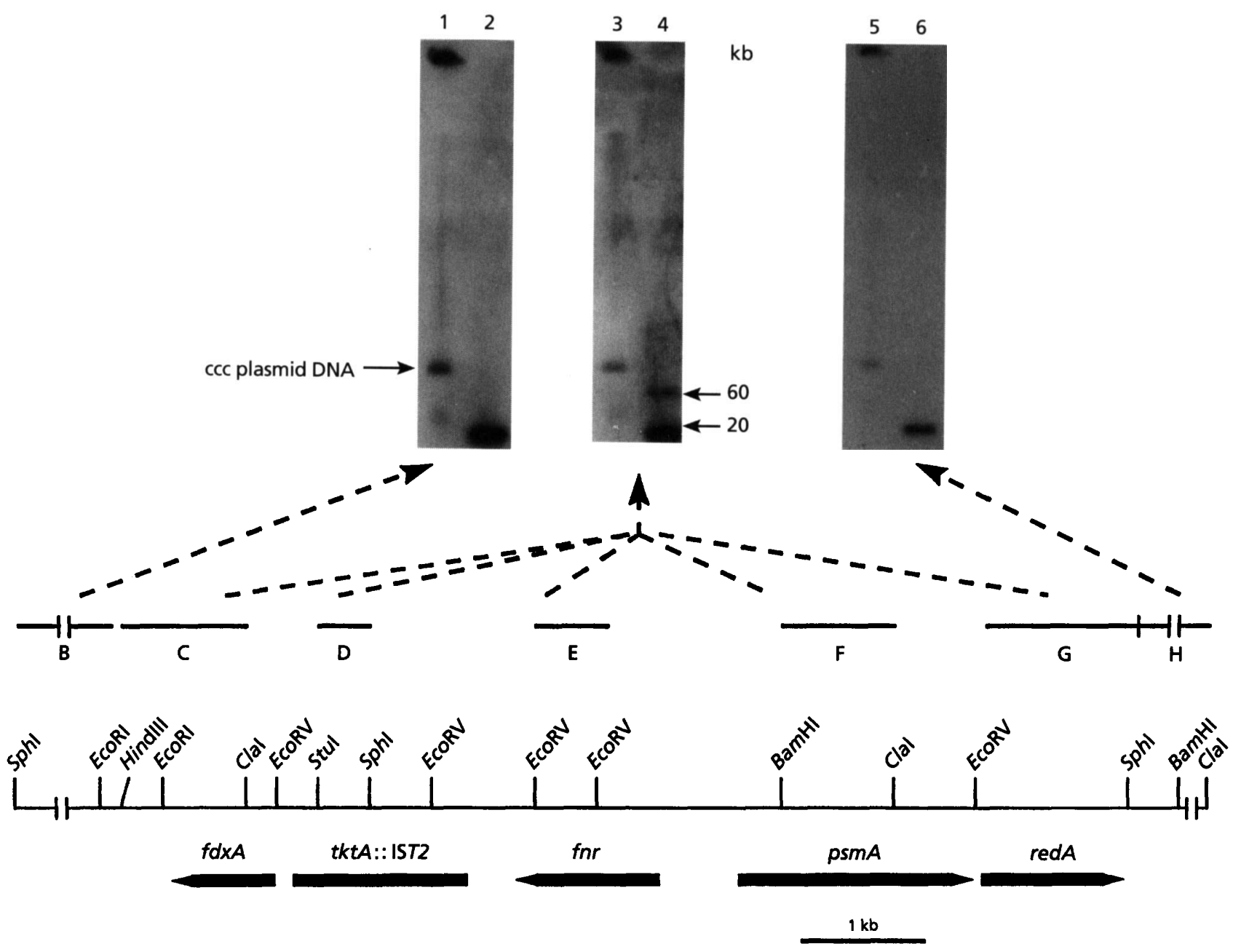

Fig. 1. Southern hybridization of T. ferrooxidans ATCC 33020 total genomic DNA separated by PFGE. Lanes: 1, 3 and 5 , undigested genomic DNA; 2,4 and 6 , genomic DNA digested with $X$ bal. The location of probes $B-H$ are indicated above the restriction map. The centre panel represents hybridization of probes C-G since the result for each probe was identical.

one. Twofold dilutions of each sample were bound to Hybond-N + membrane (Amersham) and hybridized with pCD200 digoxigenin-dUTP-labelled DNA. Copy number was determined by comparing the hybridization signal intensities of the genomic and plasmid dilution series.

General methods. DNA extraction and manipulation was carried out according to Sambrook et al. (1989). In Southern hybridization experiments, dUTP-digoxigenin-labelled DNA probes were labelled with the randomly primed DNA labelling kit (Boehringer Mannheim) and non-radioactive detection was carried out with the DIG Nucleic Acid Detection kit (Boehringer Mannheim). DNA sequencing was done by the dideoxy chain-termination method (Sanger et al., 1977) and templates were labelled using the Sequitherm kit (US Biochemical) with Cy5 fluorescent label. Automated sequencing was carried out on a Pharmacia Alf Express according to the manufacturer's instructions. In vitro proteins were generated using an E. coli transcription-translation kit (Promega) using $\left[\mathrm{S}^{35}\right]$ methionine label. SDS-PAGE was done according to
Laemmli (1970). Polyacrylamide gels were run at $120 \mathrm{~mA}$ constant current for $12 \mathrm{~h}$. Sequence was analysed using the UWGCG (Devereux et al., 1984) set of programs. Homology searches were performed using the BLAST algorithm (Altschul et al., 1990) with BEAUTY post-processing (Worley et al., 1995).

\section{RESULTS}

\section{Plasmid isolation using a metronidazole reduction assay}

Plasmid pTF5 was isolated from a $T$. ferrooxidans total DNA cosmid library during a screening procedure designed to select genes which express redox-active proteins. The $E$. coli mutant F19 is partially resistant to metronidazole and lacks the ability to reduce the drug (Santangelo et al., 1991). Several cosmids were isolated 


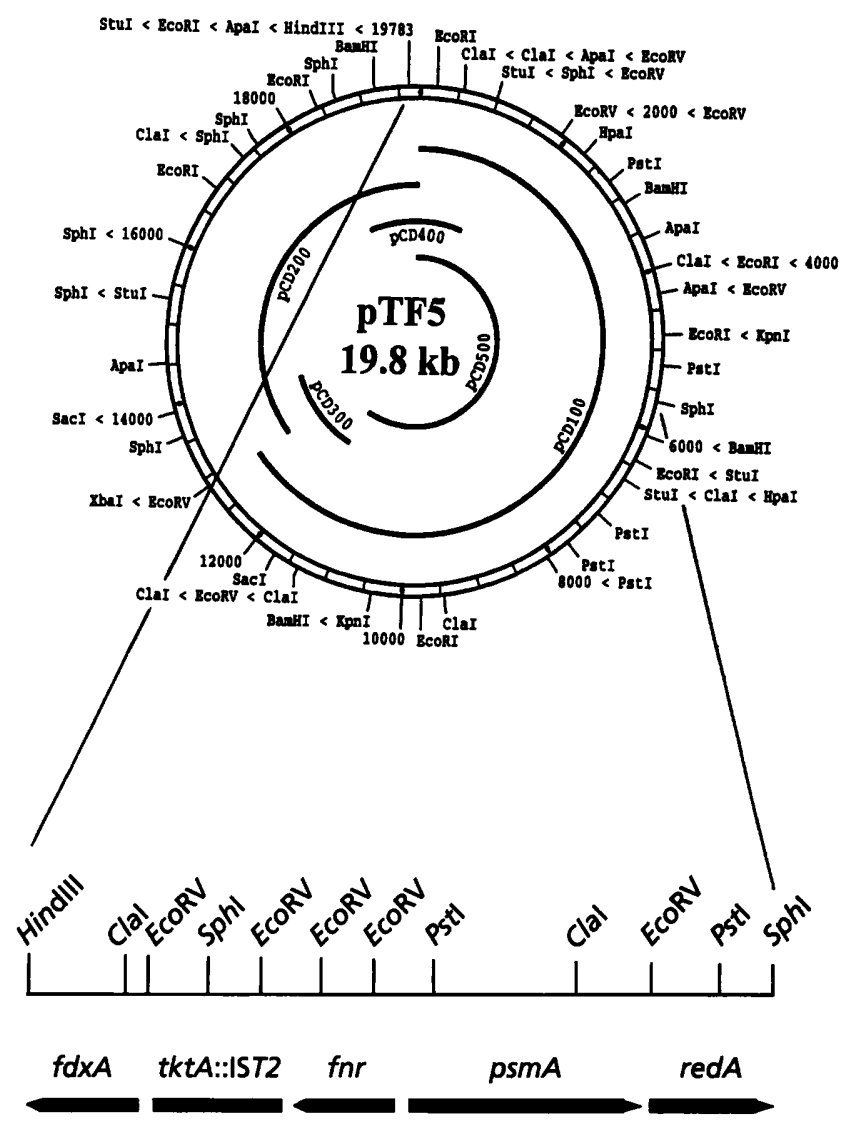

Fig. 2. Restriction enzyme cleavage map of pTF5 showing the location and genetic map of the region which is present on both plasmid and chromosome. The subclones used for location of the region which resulted in metronidazole sensitivity of the $E$. coli F19 mutant are indicated in the centre of the map.

which restored wild-type levels of metronidazole sensitivity to E. coli F19. These cosmids were digested with a number of restriction enzymes and the sizes of several of the fragments were found to be similar (data not shown). Two of the cosmids, pMET7 and pMET17 were selected for further study. To confirm that pMET7 and pMET17 contained overlapping clones of the same region of $T$. ferrooxidans DNA, a $1.0 \mathrm{kbp}$ fragment (probe C, Fig. 1) common to both cosmids was labelled and probed against a blot of digested and undigested total DNA isolated from $T$. ferrooxidans. When undigested total DNA is separated using PFGE, chromosomal DNA remains in the well but plasmid DNA migrates into the gel in a pulse-independent manner (Hightower et al., 1987). Unexpectedly, a positive hybridization signal was obtained for undigested plasmid DNA (Fig. 1, lane 3) and two signals at $20 \mathrm{kbp}$ and approximately $60 \mathrm{kbp}$ were obtained for total DNA digested with $\mathrm{XbaI}$ (Fig. 1, lane 4). This indicated that DNA common to PMET7 and PMET17 was present on a plasmid and that DNA with homology to the probe was also present on the chromosome. This finding was confirmed using probes $C-G$ (Fig. 1), which indicates that only this region is also present on the chromosome.
Using probes $C-G$, the relative intensities of the two bands remained constant irrespective of probe or washing temperature, indicating that the plasmid and chromosomal copies were identical or nearly identical.

\section{Cloning and restriction enzyme map of pTF5}

The Southern hybridization experiment indicated that part of the insert DNA of pMET7 and pMET17 originated from a plasmid. Surprisingly, the restriction enzyme maps of portions of the two cosmids were identical to the map of pTF35, a plasmid from a different T. ferrooxidans strain (TF35) that had been cloned previously (Rawlings et al., 1983; Rawlings \& Woods, 1985). As plasmid pTF5 contained unique HindIII and $X b a \mathrm{I}$ restriction sites, intact $\mathrm{pTF} 5$ was reassembled and cloned by ligation of a $6.9 \mathrm{kbp} \mathrm{Xba \textrm {I } - H i n d I I I}$ fragment from pMET17 to a $12.9 \mathrm{kbp} \mathrm{XbaI-HindIII} \mathrm{fragment}$ from pMET7 by inserting the $19.8 \mathrm{kbp}$ HindIII-XbaI-HindIII fragment into the HindIII site of the cloning vector, pBluescript KS (pBS-KS). The resultant construct, $\mathrm{pCD} 1$, was digested with a number of restriction enzymes and the sizes of the fragments compared with pTF35, which had previously been cloned into pBR322 (pDER301) (Rawlings \& Woods, 1985). Plasmids pCD1 and pDER301 were digested with HindIII to free pTF5 and pTF35 from their respective cloning vectors and then digested with a second restriction endonuclease (either BamHI, ClaI, EcoRI, HpaI or SalI). Plasmids pTF5 and pTF35 gave fragments of identical size (not shown) and the sizes of the fragments corresponded to the restriction map reported for pTFO (Valenti et al., 1989).

\section{Identification of the region conferring metronidazole sensitivity}

The MIC of metronidazole for E. coli F19 containing cosmids, cloned pTF5 (pCD1) and relevant subclones was determined. E. coli containing $\mathrm{pBS}-\mathrm{KS}$ or pUCBM21 plasmid or $\mathrm{pHC79}$ cosmid vectors was resistant to metronidazole (MIC $20 \mathrm{mg} \mathrm{l}^{-1}$ ) while cosmids pMET7 and pMET17 conferred metronidazole sensitivity (MIC $10 \mathrm{mg} \mathrm{l}^{-1}$ ). Cloned pTF5 (pCD1) as well as subclones pCD100 and pCD300 (Fig. 2) conferred metronidazole sensitivity, while subclones pCD200, pCD400 and pCD500 were metronidazole-resistant. A 319 bp XbaI-SalI fragment subclone of pCD300 was on its own responsible for full metronidazole sensitivity and this insert fragment was sequenced. It was unexpectedly found to have extensive nucleotide homology $(98 \%)$ to part of a recently described origin of vegetative replication (oriV) from the $T$. ferrooxidans plasmid pTFI91 (Chakravarty et al., 1995).

\section{DNA sequence analysis}

The region of pTF5 from the HindIII site (position $1 \mathrm{bp}$ ) to the $S p h$ I site $(5650 \mathrm{bp}$ ) was sequenced on both strands and is shown in Fig. 3. Four complete ORFs and two 
HindIII

1 AAGCTTACGTAGAAACGTGCTGGGCCCAGGAACTCCACCCGGTGCGGCAGATCGGGCGTATCCATGCAGGCCGTCCGA

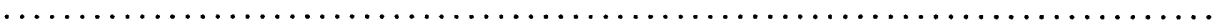

241 CAAGGGCACGGGCGGCTCGGGCAGGGGCAATTCCTCCTCCTCTTCCCCGGTATCCAGATATGGGCGTTTATCCCGCACAT $\begin{array}{lllllllllllllllllllllllllllll}* & \mathbf{P} & \mathbf{C} & \mathbf{P} & \mathbf{R} & \mathbf{S} & \mathbf{P} & \mathbf{C} & \mathbf{P} & \mathbf{C} & \mathbf{N} & \mathbf{R} & \mathbf{R} & \mathbf{R} & \mathbf{K} & \mathbf{G} & \mathbf{P} & \mathbf{I} & \mathbf{W} & \mathbf{I} & \mathbf{H} & \mathbf{A} & \mathbf{N} & \mathbf{I} & \mathbf{G} & \mathbf{C} & \mathbf{M}\end{array}$

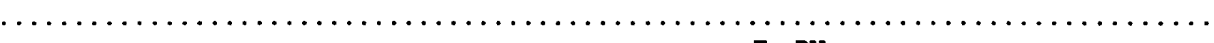
ECORV

561 ATCGGTATACTTACACCGAATACAGGCTTCTGTAACCACATGGGTCATTGGATATCCCCCTTAACGTATGCCCCGGAAAT $\begin{array}{lllllllllllllllll}D & T & Y & K & C & R & I & C & A & E & T & V & V & H & T & M & \text { fdren }\end{array}$ GCCTTCAACGCCAGATCGGCGGGATTGCGCTCGCCCCATTTCCGAAAATCCGTCAAAACCGMYCAYCACGGCGTATAAAA $\begin{array}{lll} & -10 & N_{17}\end{array}$ GATGCCTCMTCAGAACTTCATGTCGATAAACGGATAGATTTTATACCTATCCCGCGACTCGCCCGCGTTATAGTAGCCG $-35$

TTGGGCTTCCTGTACCACATTTTCCACAGTGAATCCCAGATGGCGGAAATTTTCTGGATAGGGTGCACTGGCGCCGAAGC $\begin{array}{llllllllllllllllllllllllllll}\mathbf{Q} & \mathbf{A} & \mathbf{E} & \mathbf{Q} & \mathbf{V} & \mathbf{V} & \mathbf{N} & \mathbf{E} & \mathbf{V} & \mathbf{T} & \mathbf{F} & \mathbf{G} & \mathbf{L} & \mathbf{H} & \mathbf{R} & \mathbf{F} & \mathbf{N} & \mathbf{E} & \mathbf{P} & \mathbf{Y} & \mathbf{P} & \mathbf{A} & \mathbf{S} & \mathbf{A} & \mathbf{G} & \mathbf{F}\end{array}$

881 GGCTCAGGCCTATGGTGGCGCCCTCTCCCACCCATTCGCACCACCCCAGGGATGCCGCAGCCTCTACGGCGAGCCGGACT

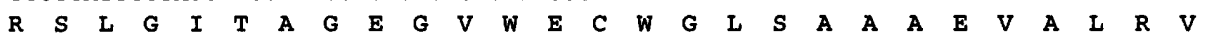
tranmketolane homology

TTGATATTCCGTGGGAGCACCGTATCCCGGTAAGCGGCCGGCTGGGCGCGGAATATCTCCCAGCTGGGCATGCTCTTCGC

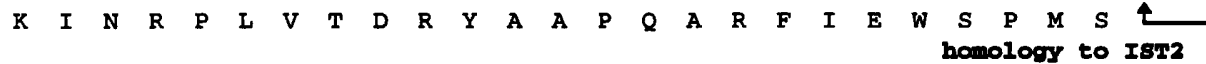

1441 CCAGTTTCGATCATAGCTCTCCGCATTGGCGTTCCTTCAGGACAATGCGGTGCGCGATGTGGCCCCAGTTTGGCTGACAG IsH2 homology

1521 AGCCAGGCCCCCTCGTGTAGCTGATGAGATCGTTATTGATTGGATGACGCTTGCGGCGAACGGTGAAACCTATTTCCTG

1601 TCATCTACCGGGTAGACGATTTGCTGTTCGCCCATTGCCGTAACTCAGAAGGGCGTGGATGTATATCTTGAGTTTTTCA

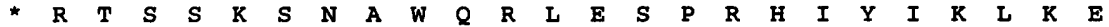

2241 ATCCGACCAGACAGAGAATATTCTGTTCGGCGCATCGCTCCATTTCTGTTAACTCTACTTGGCCGATTGTCATCAATC \begin{tabular}{lllllllllllllllllllllllll}
$D$ & $S$ & $W$ & $V$ & $S$ & $F$ & $I$ & $E$ & $T$ & $R$ & $R$ & $L$ & $R$ & $E$ & $M$ & $E$ & $T$ & $L$ & $E$ & $V$ & $Q$ & $G$ & $I$ & $T$ & $M$ \\
\hline
\end{tabular}

TGGCTTTTGGGCGAACAAAACTGTGTCTAAAACCATCTTTACCCCATGATGCGGCTTTTACGGACCATAACTCAGCCTGT

2401 TATGTGCCTGCGGGTGCGTCTCGCAGGCGGATTCAGCCGCCGGATTCCAGACAATTGATCGGGATAGGCGGAGCGTAGT

2481 GTGACGTTAAATACGTTACGCCGAATCTCCGGGCAGGGTCAATCGCCTGTCTTTTGCTTAGGGTTTCCCGTCGACGATCA $\sin$ box

2561 TGAGGAATGCGCAGCCACTMATTGAATCAAGGATGGTCCTGATCACAGCAGATATTGTTGACAAACAAGCACCACAAC

2641 CTCAGGAGACACCATGATGTTTTGCTATCAATGCGAACAAACCACCCGCAGCCCCGCCGGATAGGCTGTACCAGTGAGC

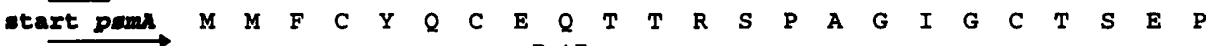
PstI

4241 CTCCAATCACGTTTCGATCTTGATCTCGATCTTATTGGCGAGGCGCAAGCGGATTTGCAGGCGGCTCTGGCGCATACGGC $\begin{array}{lllllllllllllllllllllllllllll}L & Q & S & R & F & D & L & D & L & D & L & I & G & \text { E } & A & Q & A & D & L & Q & A & A & L & A & H & T & A\end{array}$ Q ECORV

4321 GTAGCACAATGGAACGCCGCTTCGTTCTGCAACGGACGAAGCGGATAAGGATGAGCAGATCATGACCAACTACGATATC *

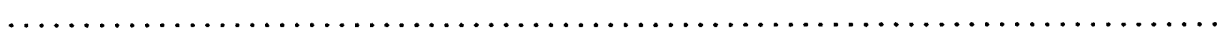

5361 CAAGGGTGCCGGACTCCTGTTTGCAGTTCGAACGGTTTTGTCCGCATAGTGCAATGTCTATAGACTTGCTAGAACCAT

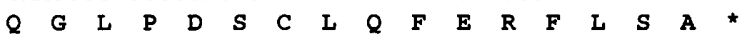
$\ldots \ldots \ldots \ldots \ldots \ldots \ldots \ldots \ldots \ldots \ldots \ldots \ldots \ldots \ldots \ldots$

5601 CGCAGTTTCTTGATAATGGCAATTTCCCGATTATCCTGTGGCATGC

Fig. 3. Relevant portions of the HindIII-Sphl fragment of pTF5. Dotted lines indicate gaps in the nucleotide sequence. The amino acid sequence of the predicted proteins and products of partial ORFs are shown below the nucleotide sequence. Potential ribosome-binding sites are underlined, the FNR consensus binding site is in bold type, inverted repeat sequences between psmA and redA are represented as an inverted pair of arrows, the transposition scar is italicized, the directions of transcription are indicated by short arrows and the putative ferredoxin promoter is shown as bold and underlined. 
truncated ORFs were identified within the $5.65 \mathrm{kbp}$ HindIII-SphI region (Fig. 2). Predicted amino acid sequences of the ORFs were compared with sequences in the non-redundant GenEMBL database using the BLAST program (Altschul et al., 1990). The ORF closest to the HindIII site consisted of 122 amino acids ( $14 \mathrm{kDa}$ ) with highest sequence homology to a [3Fe-4S,4Fe-4S] ferredoxin of 106 amino acids from Pseudomonas putida (Fig. 4a) (Hase et al., 1978). A putative $\sigma^{70}$-type promoter sequence was identified $93 \mathrm{bp}$ from the ATG start of the ferredoxin gene, $f d x A$ (Fig. 3). This promoter appeared to be functional in $E$. coli as a lacZ reporter gene fusion to the ferredoxin $\mathrm{N}$-terminus was expressed in $E$. coli (data not shown) and a protein product of the size predicted for the ferredoxin was detected in an E. coliderived in vitro transcription-translation system (Fig. 6).

Adjacent to the ferredoxin gene was a region with an incomplete ORF of 82 amino acids which had $48 \%$ amino acid sequence identity to part of the transketolase (tktA gene) from $E$. coli (Sprenger, 1993) and which appeared to have been fused to part of an IST2-like insertion sequence (Figs 2, 3). The IST2-like insertion sequence element had $81 \%$ nucleotide sequence homology to the IST2 insertion sequence from $T$. ferrooxidans ATCC 19859 (Yates \& Holmes, 1987; Yates et al., 1988). It contained an ORF with homology to part of the presumptive IST 2 transposase except that the first $48 \mathrm{bp}$ were deleted and the ORF terminated after $462 \mathrm{bp}$. The truncated transketolase-like ORF and IST2-like element are possibly the result of insertion and deletion events associated with transposon activity such that only a transpositional 'scar' remains.

Next to the IST2-like element was another complete ORF of $26.5 \mathrm{kDa}$ which had highest amino acid sequence homology to the FNR-like protein from Pseudomonas aeruginosa (28.9\% identity) (Arai et al., 1995) and Paracoccus denitrificans (27.5\% identity) (Fig. 4b) (Van Spanning et al., 1995). FNR proteins are regulators of gene transcription and bind to a specific nucleotide consensus sequence in the promoter regions of genes they regulate (Spiro, 1994). The FNR regulator subfamily possess a C-terminal DNA recognition helixturn-helix domain containing a conserved $\mathrm{E}-\mathrm{X}_{2}-\mathrm{SR}$ motif which was also present in the FNR-like protein encoded by pTF5 (Fig. 4b). However, cysteines equivalent to the three $E$. coli FNR N-terminal Cys residues and the $\mathrm{Cys}_{122}$ residue, which are thought to function in redox sensing and FNR intramolecular coupling (Spiro \& Guest, 1988; Green et al., 1993), were not present. A perfectly conserved FNR-binding consensus sequence (TTGAT-N - -ATCAA) was found $61 \mathrm{bp}$ upstream of an ORF of 556 amino acids, designated psmA (predicted size $60.2 \mathrm{kDa}$ ) which was positioned upstream of the FNR-like ORF but translated in the opposite direction (Figs 2, 3).

The $60 \cdot 2 \mathrm{kDa}$ ORF had clear amino acid sequence similarity to the predicted amino acid sequences of the three prismane genes in the GenEMBL database (Fig. $4 c)$. Prismane proteins have an unusual $[6 \mathrm{Fe}-6 \mathrm{~S}]$ pris- moidal cluster and have no known function. The pTF5 prismane-protein-like ORF had highest amino acid identity to the prismane proteins from the genus Desulfovibrio (43-46\%) (Stokkermans, 1992a, b) and slightly less homology to the protein from the archaeon Methanobacterium jannaschii (41\%) (http:// www3.ncbi.nlm.nih.gov). The three non-pTF5 prismane proteins have nine cysteine residues, four of which occur in a Cys- $\mathrm{Xaa}_{2}-\mathrm{Cys}-\mathrm{Xaa}_{7}-\mathrm{Cys}-\mathrm{Xaa}_{5}-\mathrm{Cys}$ motif located near the N-terminus (Fig. 4c). The pTF5 prismane-protein-like ORF had all four of the conserved $\mathrm{N}$-terminal Cys residues; however, the spacing (Cys$\mathrm{Xaa}_{2}-$ Cys-Xaa 11 -Cys-Xaa ${ }_{6}-$ Cys) was different.

Downstream of the prismane-protein-like ORF was an ORF of 343 amino acids (38.1 kDa) (Fig. 3). This ORF had highest amino acid sequence similarity to subunit $\mathrm{c}$ of the methane monooxygenase of Methylococcus capsulatus ( $40.5 \%$ amino acid identity) which functions as an NADH oxidoreductase (Fig. 4d) (Stainthorpe et al., 1990). A short intergenic region separated the prismane-protein-like and NADH-oxidoreductase-like ORFs, the most notable feature of which was a $10 \mathrm{bp}$ inverted repeat sequence which could form a stem-loop structure of $\Delta G-14.6 \mathrm{kcal} \mathrm{mol}^{-1}\left(-61.3 \mathrm{~kJ} \mathrm{~mol}^{-1}\right)$ and was situated immediately upstream of the ribosomebinding site of the NADH-oxidoreductase-like ORF (Fig. 3).

\section{Identification of the region of pTF5 which is also located on the chromosome of T. ferrooxidans ATCC 33020}

As both chromosomal and plasmid DNA gave a positive hybridization signal to a probe from the region containing the ferredoxin-like ORF (probe C, Fig. 1), we wished to determine whether only a portion of pTF5 was present on the chromosome or whether the entire plasmid was integrated into the chromosome. Undigested total DNA from T. ferrooxidans ATCC 33020 cells and fragments of total DNA digested with $X b a I$ were separated using PFGE. The gels were blotted and probed with digoxigenin-labelled fragments of pTF5 (Fig. 1). Probes C, D, E, F and G gave identical hybridization signals to undigested plasmid (Fig. 1, lane 3 ), and also to the $20 \mathrm{kbp}$ linearized plasmid and a $60 \mathrm{kbp}$ chromosomal fragment (lane 4). Probes B and H hybridized to a band corresponding to covalently closed circular plasmid DNA in the undigested samples and to the $20 \mathrm{kbp}$ linearized plasmid band in the $\mathrm{XbaI}$-digested DNA. No hybridization to the chromosomal band at $60 \mathrm{kbp}$ was observed with probes $B$ and $H$. This indicated that the DNA extending from probes $C$ to $G$, which included the ferredoxin-, the FNR-, the prismaneand NADH-oxidoreductase-like ORFs, was present on both plasmid pTF5 and the chromosome of T. ferrooxidans ATCC 33020. The signal obtained from the DNA in the well of the undigested samples (Fig. 1, lanes 1,3 and 5) was due to plasmid DNA becoming entangled in the chromosomal DNA and was absent from the 
(a)

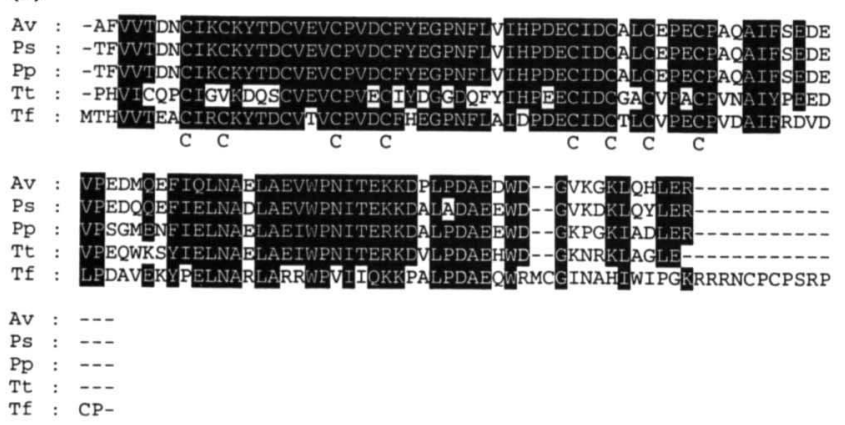

(c)
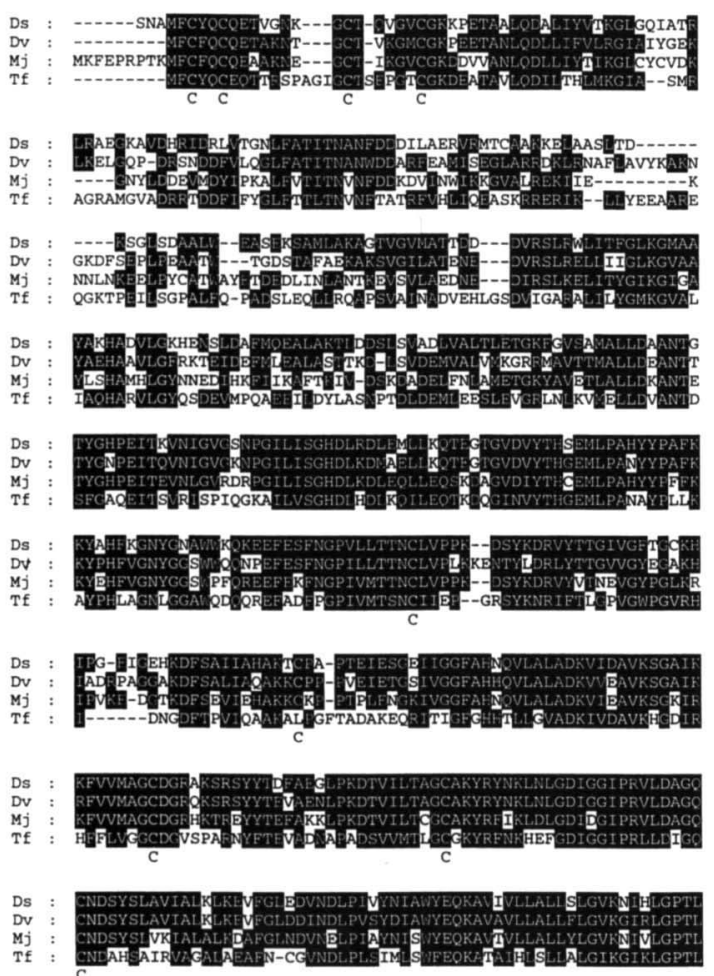

(b)

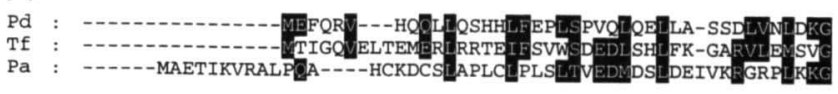

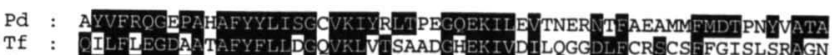

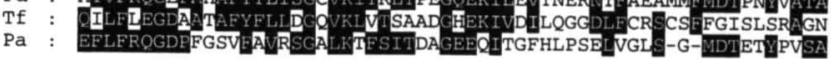

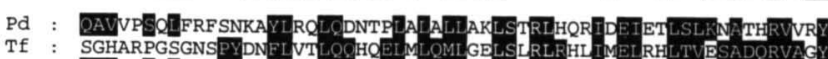
$\mathrm{Pa}$

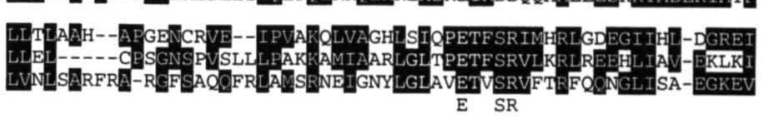
Pd : SILERERIECFE--------
Tf : YIHRPSELRQWANSKSSTR-
Pa : HILDSIELCALAGGQLG--

(d)
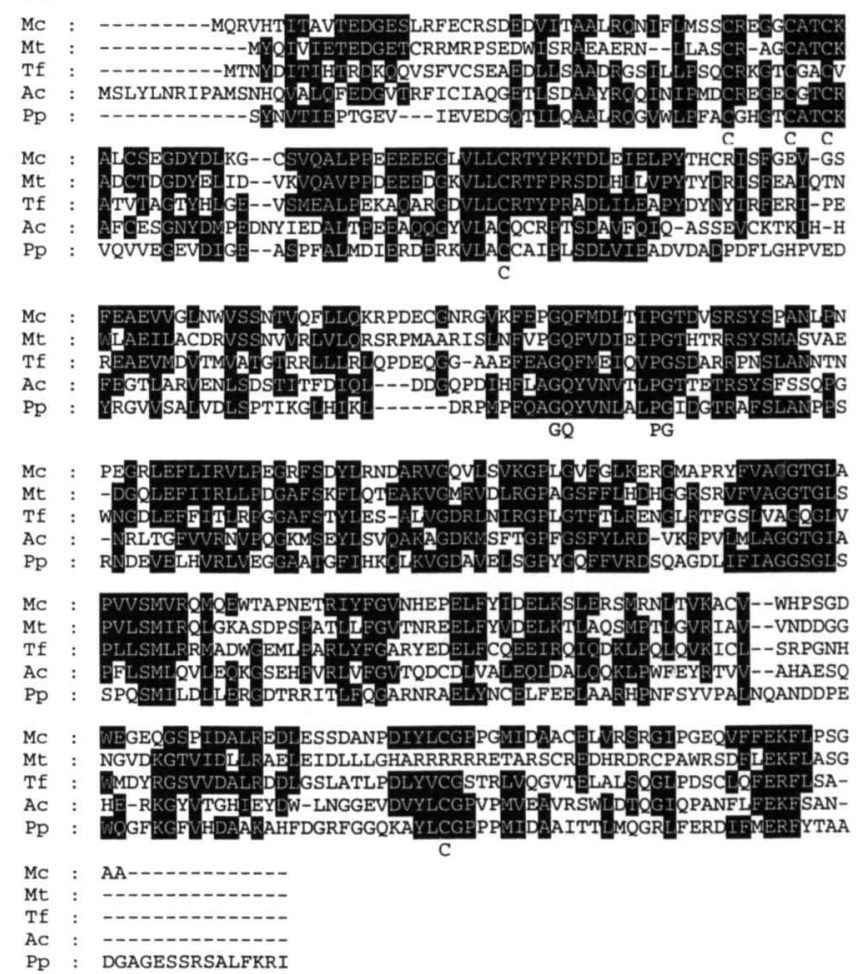

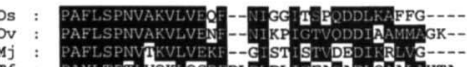

Fig. 4. Alignment of the FNR-like and iron-sulphur proteins of pTF5 with the proteins from the GenEMBL database which showed the greatest amino acid sequence similarity. Identical or similar amino acids are shown against a black background. Conserved cysteine residues $(C)$ in the iron-sulphur proteins, the $E-X_{2}-S R$ motif in the C-terminal region of the FNR-like protein and a potential NAD-binding domain in the NADH-oxidoreductase-like ORF (GQ- $\left.\mathrm{X}_{6}-\mathrm{PG}\right)$ are marked below the sequences. (a) The [3Fe-4S,4Fe-4S] ferredoxin-like ORF. Av, Azotobacter vinelandii; Ps, Pseudomonas stutzeri; Pp, Pseudomonas putida; Tt, Thermus thermophilus; Tf, Thiobacillus ferrooxidans. (b) The FNR-like ORF. Pd, Paracoccus denitrificans; Tf, T. ferrooxidans; Pa, Pseudomonas aeruginosa. (c) The prismane-protein-like ORF. Ds, Desulfovibrio sulphuricans; Dv, Desulfovibrio vulgaris; Mj, Methanococcus jannaschii; Tf, T. ferrooxidans. (d) The NADHoxidoreductase-like ORF. Mc, Methylococcus capsulatus; Mt, Methylosinus trichosporium; Tf, T. ferrooxidans; Ac, Acinetobacter calcoaceticus; Pp, P. putida.

DNA in the lanes digested with XbaI (Fig. 1, lanes 2, 4 and 6).

The experiment shown in Fig. 1 also enabled the approximate position of the junction between plasmidspecific DNA and the DNA present on both pTF5 and the chromosome to be determined. Since DNA probe B was the closest probe to the ferredoxin-like ORF which gave a hybridization signal to plasmid DNA only and as probe $\mathrm{C}$ gave a signal to both plasmid and chromosomal DNA, the junction was localized to the region within probe $\mathrm{C}$, most likely in the 215 bp DNA EcoRI-HindIII 
Amount of probe (pg)

$768038401920960 \quad 480 \quad 240 \quad 120$

60

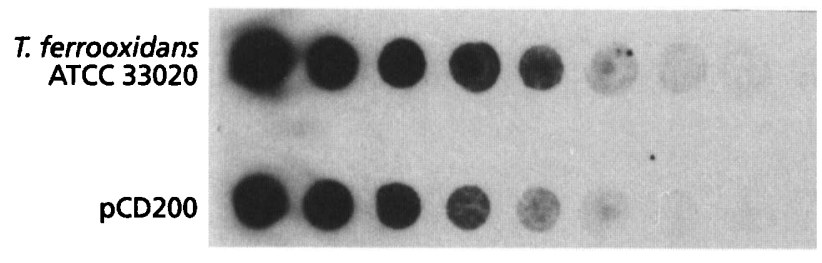

Fig. 5. Dot blot hybridization to determine pTF5 copy number in T. ferrooxidans. Upper row, T. ferrooxidans ATCC 33020 total genomic DNA; lower row, pCD200 DNA. Samples of DNA were standardized according to the relative sizes of the $T$. ferrooxidans chromosome and plasmid pTF5 assuming a pCD200 copy number of one in each sample.

fragment immediately downstream of the ferredoxinlike ORF. Similarly, analysis of the signals obtained from probes $\mathrm{G}$ and $\mathrm{H}$ enabled localization of the righthand junction between plasmid and chromosome to a region within probe $\mathrm{G}$, most likely the $531 \mathrm{bp}$ SphI-BamHI fragment downstream of the NADHoxidoreductase-like ORF (Fig. 1). No transposon termini, inverted repeats, direct repeats or features frequently identified with transposon activity were obvious within either junction region.

\section{Determination of plasmid copy number in T. ferrooxidans}

The copy number of pTF5 was estimated by hybridization of a plasmid probe, pCD200 (Fig. 2), to known amounts of purified plasmid and total DNA prepared from $T$. ferrooxidans in a dot blot experiment. Based on the relative intensities of the hybridization signals, pTF5 was estimated to be present at between two and four copies per chromosome (Fig. 5). This estimate was supported by the observation that the intensity of the signal to hybridization probes $C-G$ was consistently three- to fourfold greater than to the chromsomal bands (Fig. 1).

\section{Expression of proteins from pTF5}

We wished to determine whether any of the ORFs from the region of pTF5 that was present on both chromosome and plasmid were expressed. An E. coli-derived in vitro transcription-translation system was used to detect expression of plasmid-encoded proteins even though it had the disadvantage that not all factors required for expression might be present in the heterologous system. It was used because even if protein-specific antibodies had been available, they would not have assisted in identifying whether antibody-specific proteins produced by $T$. ferrooxidans originated from the plasmid or the chromosome since the same genes were present on both. Polypeptides produced from pTF5 using the E. coli system are shown in Fig. 6. Comparison of polypeptides produced from pCD1 (lane 2) with those produced by the vector $\mathrm{pBS}-\mathrm{KS}$ (lane 1) indicated that additional proteins of approximately $90,40,26,17$, and at least two between 14 and $9 \mathrm{kDa}$ were produced from pTF5. To identify whether any of these polypeptides were expressed from the region of pTF5 which was also present on the chromosome, small fragments containing each of the ORFs were cloned into pBS-KS so that they were in the same orientation as the lac $Z$ vector promoter. A $14 \mathrm{kDa}$ polypeptide was detected from the clone pCD421 containing the ferredoxin-like ORF (lane 3 ). The proteins at approximately $28 \mathrm{kDa}$ were spurious proteins produced from the $l a c Z$ vector promoter which (in this particular construct) was facing in the opposite direction to the $f d x A$ gene. A $60 \mathrm{kDa}$ protein was expressed from the clone of the prismane-like ORF, pCD119 (lane 6) and a 37 and $39 \mathrm{kDa}$ protein doublet from the clone of the NADH-oxidoreductase-like ORF, pCD163 (lane 7). The $60 \mathrm{kDa}$ prismane-like protein and the 37 and $39 \mathrm{kDa}$ doublet corresponding to the NADHoxidoreductase-like proteins were synthesized when expressed behind a vector tac promoter, pCD164 (lane 8). All proteins corresponded closely to the sizes predicted from the DNA sequence analysis. No additional polypeptides were produced from the insert in clone pCD120 and no $22 \mathrm{kDa}$ protein corresponding in size to the FNR-like protein was detected (not shown). In addition, attempts to complement an E. coli RM102 $f n r$ mutant for nitrate reductase induction (Birkmann $e t$ al., 1987) with the pTF5 FNR-like gene (pCD120) were negative. The prismane- and NADH-oxidoreductaselike proteins were only expressed when in the same orientation as a vector promoter. A 37 and $39 \mathrm{kDa}$ protein doublet was produced when the insert of pCD150 was cloned in the same orientation as the lacZ vector promoter (lane 5), but not when cloned in the reverse direction (lane 4). Likewise the prismane- and $\mathrm{NADH}$-oxidoreductase-like proteins appeared not to be expressed from pTF5 promoters in E. coli (pCD1, lane 2 ); however the $14 \mathrm{kDa}$ polypeptide corresponding in size to the ferredoxin-like protein was expressed from pTF5 (lane 2) or when cloned in either orientation relative to a vector promoter (not shown). With the exception of the $14 \mathrm{kDa}$ protein, the proteins expressed from pCD1 appeared to have originated from DNA found on the part of pTF5 that was not present on the chromosome.

\section{Presence of plasmids with homology to PTF5 in $T$. thiooxidans, $L$. ferrooxidans and other strains of T. ferrooxidans}

The presence of pTF5-like plasmids among five $T$. ferrooxidans strains not previously tested, including four strains which were isolated in South Africa, was examined. Undigested and XbaI-digested total DNA was subjected to PFGE and a Southern hybridization experiment carried out using probe G (Fig. 1). Positive hybridization signals to plasmids present in $T$. ferrooxidans strains ATCC 23270 (USA), ATCC 33020 

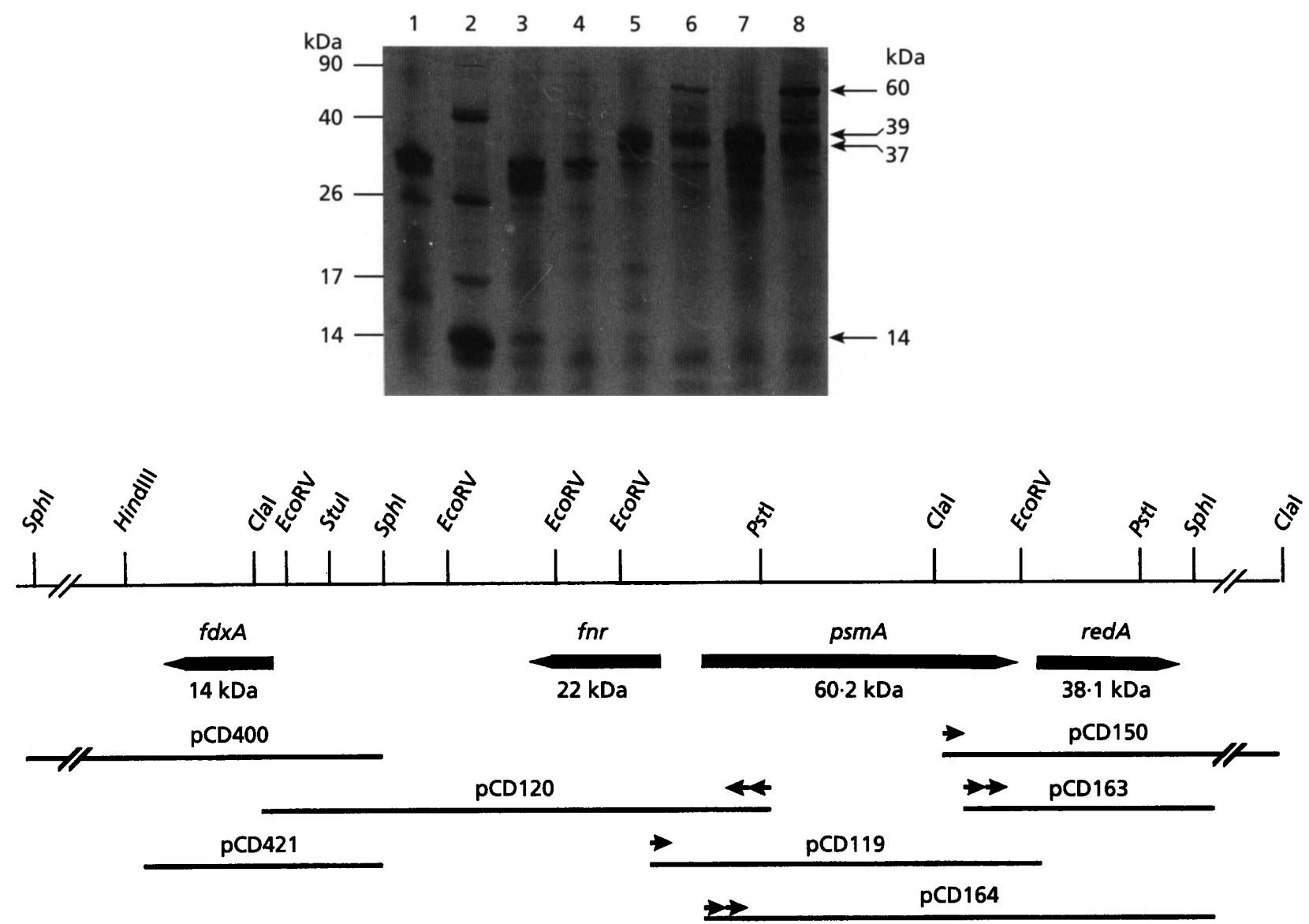

Fig. 6. SDS-PAGE analysis of polypeptides translated in vitro from pCD1 (pTF5 cloned into pBS-KS) and pTF5 subclones. The location of the constructs tested is shown below the PAGE gel and the direction of vector promoters indicated by one (lacZ promoter) and two (tac promoter) arrowheads. Lanes: 1, pBS-KS vector control; 2, pCD1; 3, pCD421; 4 and 5, pCD150 in both vector orientations; 6, pCD119; 7, pCD163; 8, pCD164.

(a)

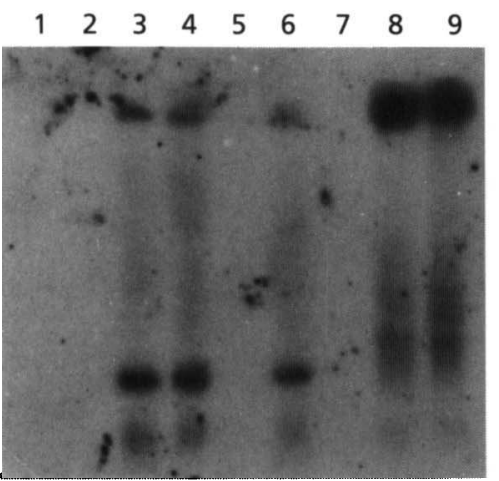

(b)

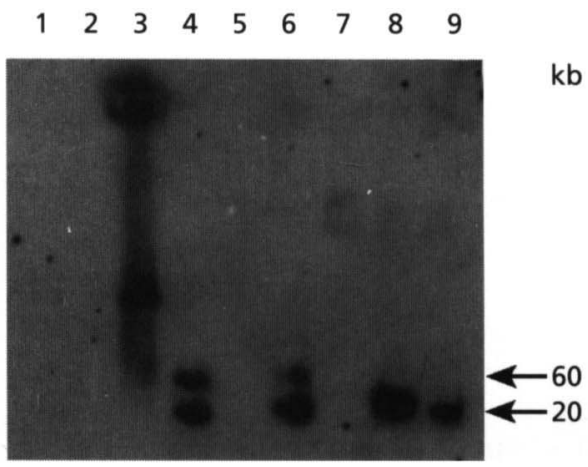

(c)

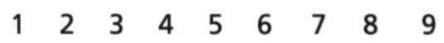

Fig. 7. Southern hybridization of total DNA separated by PFGE from a number of bacterial strains. (a) Undigested total DNA hybridized to probe G; (b) total DNA digested with Xbal which hybridized to probe G; (c) undigested total DNA probed with pCD300. Lanes: 1, L. ferrooxidans DSM 2705; 2, T. thiooxidans ATCC 19377; 3, T. ferrooxidans ATCC 23270; 4, T. ferrooxidans ATCC 33020; 5, molecular mass markers; 6, T. ferrooxidans FC1; 7, T. ferrooxidans FC6; 8, T. ferrooxidans Black mountain $\mathrm{Pb}$; lane 9, T. ferrooxidans Bateman Reno. 
(Japan) and FC1 (South Africa) were obtained (Fig. 7a, lanes 3, 4 and 6). The hybridization signal to DNA remaining in the well of each of these strains was due to non-mobile undigested chromosomal DNA and possibly some entrapped plasmid DNA. In the case of $T$. ferrooxidans strains Black Mountain $\mathrm{Pb}$ and Bateman Reno (Fig. 7a, lanes 8 and 9), a hybridization signal for DNA remaining in the wells was obtained but there was no evidence of plasmid DNA. The XbaI-digested DNA samples from all strains confirmed these results. Two bands were obtained for T. ferrooxidans strains ATCC 23270, ATCC 33020 and FC1 (Fig. 7b, lanes 3, 4 and 6), one signal due to the copy of the $\operatorname{red} A$ gene on the plasmid and the other due to the chromosomal copy. In the case of strain ATCC 23270 (lane 3), the chromosomal DNA migrated only a short distance from the well as it was on an $\mathrm{XbaI}$ fragment of greater than $500 \mathrm{kbp}$ and fragments of this size do not penetrate the gel under the running conditions used to separate smaller fragments. From the XbaI-digested samples it may be seen that the plasmid in strain ATCC 23270 was clearly of larger size than the plasmids in strains ATCC 33020 or FC1 (Fig. 7b, lanes 3, 4 and 6). T. ferrooxidans strains Black Mountain $\mathrm{Pb}$ and Bateman Reno gave only a single hybridization signal at about $30 \mathrm{kbp}$ (Fig. $7 \mathrm{~b}$, lanes 8 and 9), slightly larger than the digested plasmids in strains ATCC 33020 and FC1 and smaller than the signal from the chromosomal copy in those strains (Fig. $7 \mathrm{~b}$, lanes 4 and 6). No signal was obtained for either $L$. ferrooxidans type strain DSM 2705, T. thiooxidans type strain ATCC 19377 or T. ferrooxidans FC6 (Fig. 7a, b, lanes 1, 2 and 7).

The same membrane filters shown in Fig. $7(\mathrm{a}, \mathrm{b})$ were stripped and probed with labelled DNA from the plasmid origin of replication (pCD300; Fig. 2). Only the result of reprobing the filter shown in Fig. 7(a) is presented in Fig. $7(\mathrm{c})$. As predicted, a hybridization signal to a single plasmid band in strains ATCC 23270 , ATCC 33020 and FC1 was obtained (Fig. 7c, lanes 3, 4 and 6). Unexpectedly, hybridization signals to strains Black Mountain $\mathrm{Pb}$ and Bateman Reno were obtained to DNA in the wells (Fig. 7c, lanes 8 and 9). This implies that a plasmid with homology to pTF5 had become integrated into the chromosome of these strains.

\section{DISCUSSION}

The intial aim of this study was to identify T. ferrooxidans electron transport genes which reductively activate metronidazole. For example, reduced ferredoxin has been reported to transfer electrons directly to metronidazole and produce the reduced toxic derivative (Edwards \& Mathison, 1970). Futhermore, an identical screening procedure had been used to screen a gene bank from Clostridium acetobutylicum and a gene for a flavodoxin which rendered the E. coli F19 mutant sensitive to metronidazole was isolated (Santangelo et al., 1991). The pTF5 genes whose products have homology to redox-active proteins are exactly the type of genes that we would have expected to have isolated using the metronidazole activation procedure. However, the region of pTF5 which encoded these proteins was not associated with increased metronidazole sensitivity (Table 1 ). Instead, a $319 \mathrm{bp}$ region from the origin of replication which was almost identical to the previously sequenced replicon of plasmid pTFI91 (Chakravarty et al., 1995) and which did not contain an ORF was the region of pTF5 associated with increased metronidazole sensitivity. In at least two other studies similar unexpected results have been obtained. In these studies two fragments of DNA from C. acetobutylicum which resulted in increased sensitivity of E. coli F19 mutants to metronidazole and which did not encode metronidazole-reducing proteins were isolated. One of the fragments had sequence homology to tRNA genes (Sealy, 1993) whilst the other encoded the regA gene, which produced a $35 \mathrm{kDa}$ protein with homology to the LacI family of repressor proteins (Davison et al., 1995). Some members of the LacI family are repressors of tRNA genes (Leclerc et al., 1990) and it is possible that the cloned tRNA genes had sites which bound and titrated members of this repressor family. We speculate that DNA fragments and proteins which do not themselves have metronidazole-reducing activity may confer increased metronidazole sensitivity via an indirect mechanism. For example, these DNA fragments could possess a binding site for a repressor of one of the E. coli genes, the product of which is able to reduce metronidazole. This would have the effect of derepressing this gene and result in an increased metronidazole sensitivity.

Two features of plasmid pTF5 that are especially noteworthy are its wide geographical distribution among $T$. ferrooxidans strains and the discovery that it has a segment of DNA which is also present on the chromosome. In this study, the geographical distribution of the plasmid was extended from $T$. ferrooxidans strains found in the Northern hemisphere to strains found in South Africa. Even though it is widely distributed, pTF5 is not completely ubiquitous as $T$. ferrooxidans strain FC6 (Fig. 7a, b, c, lane 7) and other T. ferrooxidans strains (Valenti et al., 1989) do not possess the plasmid.

In T. ferrooxidans strain ATCC 23270 a plasmid with homology to the NADH oxidoreductase region of pTF5 (probe G) was of a larger size than pTF5. No hybridization signal to plasmid DNA in $T$. ferrooxidans strains Black Mountain $\mathrm{Pb}$ and Bateman Reno was detected when either a pTF5 replicon probe or a NADHoxidoreductase probe (probe G) was used. However, positive hybridization to chromosomal DNA from both these strains with both probes was obtained. The most likely explanation for this is that DNA with homology to the pTF5 replicon (probe pCD300) and the NADH oxidoreductase (probe $G$ ) had become integrated into the chromosome. Particularly interesting was the observation that $T$. ferrooxidans strain FC6 did not have DNA with homology to probe $G$ on either a plasmid or its chromosome (a similar result was obtained for two other South African isolates of $T$. ferrooxidans; data not 
shown). This implies that the genes present on PTF5 are not essential for the growth of $T$. ferrooxidans.

Studies on whether genes present on both the chromosome and plasmid are expressed in T. ferrooxidans are complicated by the difficulty in determining whether RNA transcripts or translation products originate from the plasmid or chromosomal copies of the gene. With the exception of the ferredoxin, no polypeptides corresponding in size to the FNR-like, prismane-like or NADH-oxidoreductase-like ORFs were detected in the $E$. coli-derived in-vitro transcription-translation system in the absence of an $E$. coli vector promoter. However, when cloned behind an $E$. coli vector promoter, products corresponding to the latter two ORFs were detected. It is likely that the ORFs of the ferredoxin-, prismane- and NADH-oxidoreductase-like proteins represent functional genes but that some of the factors required for their expression in $E$. coli were absent in the in-vitro system. Although a product corresponding to the FNR-like protein regulator was not detected in the E. coli in-vitro system nor in the in-vivo complementation assay, it is probable that an FNR-like protein is involved in the expression of the prismane-like protein as a consensus FNR-binding site was found upstream of the prismane protein gene. The presence of the E- $\mathrm{X}_{2}-\mathrm{SR}$ motif in the predicted DNAbinding C-terminal domain of the FNR-like protein suggests that this protein may be the regulator of the prismane gene.

The ferredoxin-, prismane- and NADHoxidoreductase-like proteins are likely to be part of an electron transfer system. The combination of proteins has similarity to the electron transport chain involved in the degradation of aromatic and other compounds, in which electrons are transferred from $\mathrm{NADH}$ via a flavin (and/or ferredoxin) to a terminal oxygenase (Mason \& Cammack, 1992). The NADH-oxidoreductase-like subunit on pTF5 was most similar to that of subunit $c$ of the methane monooxygenase from Metbylococcus capsulatus. The methane monooxygenase of this bacterium consists of three subunits, with subunits $a$ and $b$ together forming the terminal oxygenase and subunit $\mathrm{c}$ the NADH reductase (Stainthorpe et al., 1990). No oxygenase is apparent on pTF5 (unpublished) and the key to finding the role of the electron transport system on the plasmid might be found in discovering the function of the prismane-like polypeptide.

Prismane proteins were first discovered in sulphatereducing bacteria where Southern hybridization experiments using the Desulfovibrio vulgaris prismane protein gene as a probe showed that prismane genes were common among sulphate-reducing bacteria (Stokkermans et al., 1992a). These proteins are known to be redox-active and possess a putative [6Fe-6S] prismane cluster which is able to exist in four different redox states ranging from $[6 \mathrm{Fe}-6 \mathrm{~S}]^{6+}$ to $[6 \mathrm{Fe}-6 \mathrm{~S}]^{3+}$ (Marrit et al., 1995). Prismane proteins were reported to have no significant similarity to other proteins except within their $\mathrm{N}$-terminal regions where there is some similarity to CO dehydrogenases of Methanothrix soebngenii and Clostridium thermoaceticum (Stokkermans et al., 1992a, b). A number of activity measurements have been carried out to investigate the physiological function of the prismane protein. Hydrogen-producing hydrogenase activity, fumarate-, sulphite-, nitrite-, thiosulphate- and adenosine- 5 '-phosphosulphate reductase activities, lactate- and formate dehydrogenase activities and NADH or NADPH reactivities were all negligible (Pierik et al., 1992). The discovery of a prismane-like homologue on pTF5 has extended the biological distribution of this unusual protein, but its function and role in T. ferrooxidans is still unknown.

Since the genes discussed in this paper are present on both chromosome and plasmid, one might expect recombinative integration of the plasmid into the chromosome. As discussed earlier, integration of a pTF5 homologous plasmid into the chromosome does appear to have occurred in the case of $T$. ferrooxidans strains Black Mountain $\mathrm{Pb}$ and Bateman Reno. This raises the question of what advantage there is to the host for plasmid pTF5 to be maintained independently of the chromosome in such a large number of $T$. ferrooxidans strains from widespread geographical locations. The answer to this is not clear. The whole of pTF5 has recently been sequenced (unpublished) but all ORFs on the exclusively plasmid-associated part have homology to proteins associated with replication, invertase or recombinase functions. No ORFs have been identified which are likely to give a selective advantage to $T$. ferrooxidans strains which contain pTF5 as an independent plasmid rather than when integrated into the chromosome.

\section{REFERENCES}

Altschul, S. F., Gish, W., Miller, W., Myers, E. W. \& Lipman, D. J. (1990). Basic local alignment search tool. J Mol Biol 215, 403-410.

Arai, H., Igarashi, Y. \& Kodama, T. (1995). Expression of the nir and nor genes for denitrification of Pseudomonas aeruginosa requires a novel CRP/FNR-related transcriptional regulator, DNR, in addition to ANR. FEBS Lett 371, 73-76.

Birkmann, A., Sawers, R. G. \& Bock, A. (1987). Involvement of the ntrA gene product in the anaerobic metabolism of Escherichia coli. Mol Gen Genet 210, 535-542.

Brierley, C. L. (1982). Microbiological mining. Sci Am 247(2), $42-51$.

Chakravarty, L., Zupancic, T. J., Baker, B., Kittle, J. D., Fry, I. J. \& Tuovinen, O. H. (1995). Characterization of the pTFI91-family replicon of Thiobacillus ferrooxidans plasmids. Can J Microbiol 41, 354-365.

Clennel, A.-M., Johnston, B. \& Rawlings, D. E. (1995). Structure and function of $\operatorname{Tn} 5467$, a Tn21-like transposon located on the Thiobacillus ferrooxidans broad-host-range plasmid pTF-FC2. Appl Environ Microbiol 61, 4223-4229.

Davison, S. P., Santangelo, J. D., Reid, S. J. \& Woods, D. R. (1995). A Clostridium acetobutylicum regulator gene (regA) affecting amylase production in Bacillus subtilis. Microbiology 141, 989-996.

Devereux, J., Haeberli, P. \& Smithies, O. (1984). A comprehensive 
set of sequence analysis programs for the VAX. Nucleic Acids Res 12, 387-395.

Dorrington, R. A. \& Rawlings, D. E. (1990). Characterization of the minimum replicon of the broad-host-range plasmid pTF-FC2 and similarity between pTF-FC2 and the IncQ plasmids. $J$ Bacteriol 172, 5697-5705.

Eberhard, W. G. (1989). Why do bacterial plasmids carry some genes and not others? Plasmid 21, 167-174.

Edwards, D. I. \& Mathison, G. E. (1970). The mode of action of metronidazole against Trichomonas vaginalis. $J$ Gen Microbiol 63, 297-302.

Green, J., Sharrocks, A. D., Green, B., Geisow, M. \& Guest, J. R. (1993). Properties of FNR proteins substituted at each of the five cysteine residues. Mol Microbiol 8, 61-68.

Hase, T., Wakabayashi, S. \& Matsubara, H. (1978). Pseudomonas ovalis ferredoxin: similarity to Azotobacter and Chromatium ferredoxins. FEBS Lett 91, 315-319.

Hightower, R. C., Metge, D. W. \& Dansi, D. V. (1987). Plasmid migration using orthogonal-field-alternation gel electrophoresis. Nucleic Acids Res 15, 8387-8398.

Laemmli, U. K. (1970). Cleavage of structural proteins during the assembly of the head of bacteriophage T4. Nature 227, 680-685.

Leathen, W. W., Kinsel, N. A. \& Braley, S. A. (1956). Ferrobacillus ferrooxidans: a chemosynthetic autotrophic bacterium. $J$ Bacteriol 72, 700-704.

Leclerc, G., Noel, G. \& Drapeau, G. R. (1990). Molecular cloning, nucleotide sequence, and expression of $s h l$, a new gene in the 2minute region of the genetic map of Escherichia coli. J Bacteriol $172,4696-4700$.

Lundgren, D. G. \& Silver, M. (1980). Ore leaching by bacteria. Annu Rev Microbiol 34, 263-283.

Marrit, S. J., Farrar, J. A., Breton, J. L. J., Hagen, W. R. \& Thomson, A. J. (1995). Characterization of the prismane protein from Desulfovibrio vulgaris (Hildenborough) by low-temperature magnetic circular dichroic spectroscopy. Eur J Biochem 232, 501-505.

Mason, J. R. \& Cammack, R. (1992). The electron-transport proteins of hydroxylating bacterial dioxygenases. Annu Rev Microbiol 46, 277-305.

Pierik, A. J., Hagen, W. R., Dunham, W. R. \& Sands, R. H. (1992). Multi-frequency EPR and high resolution Mossbauer spectroscopy of a putative $[6 \mathrm{Fe}-6 \mathrm{~S}]$ prismane-cluster-containing protein from Desulfovibrio vulgaris (Hildenborough). Eur J Biochem 206, 705-719.

Polidoro, M., Buonfiglio, V., Lazzarini, M., Valenti, P. \& Orsi, N. (1993). Functional characterization of a $20 \mathrm{~kb}$ plasmid present in different Thiobacillus ferrooxidans strains. In Biohydrometallurgical Technologies, vol. II, pp. 595-602. Edited by A. E. Torma, M. L. Apel \& C. L. Brierley. Warendale, PA: TMS Press.

Powles, R. E., Deane, S. M. \& Rawlings, D. E. (1995). Molecular genetic analysis of a thioredoxin gene from Thiobacillus ferrooxidans. Microbiology 141, 2175-2181.

Ramesar, R. S. (1988). Developmental genetic studies on Thiobacillus ferroxidans. PhD thesis, University of Cape Town.

Rawlings, D. E. \& Kusano, T. (1994). Molecular genetics of Thiobacillus ferrooxidans. Microbiol Rev 58, 39-55.

Rawlings, D. E. \& Silver, S. (1995). Mining with microbes. Bio/Technology 13, 773-778.

Rawlings, D. E. \& Woods, D. R. (1985). Mobilization of Thiobacillus ferrooxidans plasmids among Escherichia coli strains. Appl Environ Microbiol 49, 1323-1325.
Rawlings, D. E., Gawith, C., Petersen, A. \& Woods, D. R. (1983). Characterisation of plasmids and potential genetic markers in Thiobacillus ferrooxidans. In Recent Progress in Biobydrometallurgy, pp. 555-570. Edited by G. Rossi \& A. E. Torma. Cagliari: Associazione Mineraria Sarda.

Rohrer, J. \& Rawlings, D. E. (1992). Sequence analysis and characterization of the mobilization region of a broad-host-range plasmid, pTF-FC2, isolated from Thiobacillus ferrooxidans. I Bacteriol 174, 6230-6237.

Sambrook, J., Fritsch, E. F. \& Maniatis, T. (1989). Molecular Cloning: a Laboratory Manual, 2nd edn. Cold Spring Harbor, NY: Cold Spring Harbor Laboratory.

Sanchez, H., Hevia, E., Caceres, B. \& Venegas, A. (1986). Studies on native strains of Thiobacillus ferrooxidans. IV. Isolation, physical map, and partial cloning of a cryptic plasmid. Biotechnol Appl Biochem 8, 300-308.

Sanger, F., Nicklen, S. \& Coulson, A. R. (1977). DNA sequencing with chain-terminating inhibitors. Proc Natl Acad Sci USA 74, 5463-5467.

Santangelo, J. D., Jones, D. T. \& Woods, D. R. (1991). Metronidazole activation and the isolation of Clostridium acetobutylicum electron transport genes. J Bacteriol 173, 1088-1095.

Sealy, V. R. (1993). A cluster of two serine transfer RNA genes from Clostridium acetobutylicum P262. MSc thesis, University of Cape Town.

Silverman, M. P. \& Lundgren, D. G. (1959). Studies on the chemolithoautotrophic iron bacterium Ferrobacillus ferrooxidans. I. An improved medium and harvesting procedure for securing high cell yields. $J$ Bacteriol 77, 642-647.

Spiro, S. (1994). The FNR family of transcriptional regulators. Antonie Leeuwenhoek 66, 23-36.

Spiro, S. \& Guest, G. R. (1988). Inactivation of the FNR protein of Escherichia coli by targeted mutagensis in the $\mathrm{N}$-terminal region. Mol Microbiol 2, 701-707.

Sprenger, G. A. (1993). Nucleotide sequence of the Escherichia coli K-12 transketolase (tkt) gene. Biochim Biophys Acta 1216, 307-310.

Stainthorpe, A. C., Lees, V., Salmond, G. P. C., Dalton, H. \& Murrell, J. C. (1990). The methane monooxygenase gene cluster of Methylococcus capsulatus (Bath). Gene 91, 27-34.

Stokkermans, J. P. W. G., Pierik, A. J., Wolbert, R. B. G., Hagen, W. R., van Dongen, W. M. A. M. \& Veeger, C. (1992a). The primary structure of a protein containing a putative [6Fe-6S] prismane cluster from Desulfovibrio vulgaris (Hildenborough). Eur J Biochem 208, 435-442.

Stokkermans, J. P. W. G., van den Berg, W. A. M., van Dongen, W. M. A. M. \& Veeger, C. (1992b). The primary structure of a protein containing a putative $[6 \mathrm{Fe}-6 \mathrm{~S}]$ prismane cluster from Desulfovibrio desulfuricans (ATCC 27774). Biochim Biophys Acta 1132, 83-87.

Valenti, P., Polidoro, M., Buonfiglio, V., Visca, P. \& Orsi, N. (1989). Comparative analysis of Thiobacillus ferrooxidans strains. In Biobydrometallurgy 1989, pp. 187-201. Edited by R. G. L. McCready \& P. L. Wichlacz. Ottawa: CANMET.

Valenti, P., Polidoro, M., Buonfiglio, V., Visca, P. \& Orsi, N. (1990). Plasmid DNA profiles in Thiobacillus ferrooxidans. J Gen Appl Microbiol 36, 351-355.

Van Spanning, R. J., de Boer, A. P., Reijnders, W. N., Spiro, S., Westerhoff, H. V., Stouthamer, A. H. \& van der Oost, J. (1995). Nitrite and nitric oxide reduction in Paracoccus denitrificans is under the control of NNR, a regulatory protein that belongs to 
the FNR family of transcriptional activators. FEBS Lett 360, 151-154.

Wall, J. D., Love, J. \& Quinn, S.P. (1984). Spontaneous Nifmutants of Rhodopseudomonas capsulata. J Bacteriol 159, $652-657$.

Worley, K. C., Wiese, B. A. \& Smith, R. F. (1995). BEAUTY: an enhanced BLAST-based search tool that integrates multiple biological information resources into sequence similarity search results. Genome Res 5, 173-184.
Yates, J. R. \& Holmes, D. S. (1987). Two families of repeated DNA sequences in Thiobacillus ferrooxidans. $J$ Bacteriol 169, 1861-1870.

Yates, J. R., Cunningham, R. P. \& Holmes, D. S. (1988). IST2: An insertion sequence from Thiobacillus ferrooxidans. Proc Natl Acad Sci USA 85, 7284-7287.

Received 3 March 1997; revised 2 July 1997; accepted 4 July 1997. 